\title{
The Effect of Board Governance and Internal Control on Investment Efficiency
}

\author{
Andrey Simonov
}

\begin{abstract}
I investigate whether board governance is associated with firm-level investment efficiency, after controlling for a firm's level of accounting quality. Prior literature finds inconsistent results for the relation between governance mechanisms and investment efficiency. I argue that managers also need strong internal controls to provide accurate information about investment projects to make efficient investment decisions. I find that strong board governance, when combined with strong internal controls over financial reporting, results in greater investment efficiency. The findings suggest that board governance and internal controls over financial reporting together enhance the monitoring role provided by financial reporting which, in turn, causes managers to more efficiently allocate firm resources, resulting in greater investment efficiency.
\end{abstract}

Index Terms-Investment efficiency, corporate governance, board of directors, internal controls.

\section{INTRODUCTION}

This study examines whether board governance mitigates investment inefficiency and whether this effect is stronger in firms with effective internal controls. Firm level investment decisions are among the most important decisions that managers make. Every year U.S. businesses spend approximately $\$ 1.6$ trillion on capital investment, which is approximately $8.4 \%$ of US GDP [1]. Prior research points out that investment decisions impact firms' long-term survival [2], firms' market value [3] and [4], prosperity of society as a whole [5]. Given the importance of firm-level investment, the attempt to understand the factors that affect investment efficiency are of practical value.

In a frictionless environment, investment opportunities are the only determinants of firm-level investment [6] and [7]. In a setting with information asymmetry, the author in [8] demonstrates a positive relation between investment expenditure and cash flow. The author in [9] extends the research by arguing that managers act to maximize the value of firm's existing equity. Managers will issue equity when based on inside information shares are overvalued. Investors observe the managers' strategy and adjust the price they are willing to pay for the new equity. This leads to underinvestment. The researcher in [10] demonstrates that managers in firms with a positive cash flow can engage in squandering funds. As a result, firms over-invest. For instance, the authors in [11] show when firms receive a cash windfall, managers do not use the cash to maximize current shareholders' value but rather they use the cash for management compensation, "empire building," diversifying acquisitions, or subsidizing poorly performing divisions [12] and [13].

Several studies attempt to examine whether corporate governance is effective in mitigating investment inefficiencies. The researchers in [14] propose an empirical design that allows to examine whether investment efficiency is driven by a higher financial leverage and a lack of access to cash. However, the authors fail to find strong support that such corporate governance mechanisms as institutional investors, number of analysts following the firm, and antitakeover protection mitigate investment inefficiency. Several studies demonstrate that corporate governance is effective in mitigating under-investment but not over-investment, others find the opposite results [15], [16].

By definition, governance mechanisms, which include board governance, ensure that suppliers of finance receive a return on their investment [17]. The reason accounting literature fails to find consistent results for the association between governance and investment efficiency is unclear. In my study, I attempt to contribute to the discussion, by examining whether stronger board governance affects investment by mitigating investment inefficiency.

In studying investment efficiency, prior literature examines whether corporate governance mechanisms are effective in aligning interests of managers and shareholders. In this study, I argue that managers also need strong internal controls to provide accurate information about investment projects to make efficient investment decisions. Internal controls include the control environment, risk assessment, control activities, monitoring, and effective communication. If any of the components fail, it potentially hinders the accuracy of information managers receive from external or internal reports and diminishes the effectiveness of investment decisions. To examine investment efficiency, I study board governance and internal controls as part of one system.

In this study, I adopt [14] model. My main results are based on the Board Index developed by RiskMetrics Group. This index is used as a proxy for the quality of a firm's board of directors based on the weights of various indicators that were determined by prior academic research.

Analyzing a sample of U.S. manufacturing, I find that board governance is an important determinant of investment efficiency and that effective internal controls facilitate the effect of board governance on both under-investing and overinvesting. I also find that strong board governance combined with weak internal controls is effective in mitigating underinvestment but not over-investment.

The remainder paper is organized as follows. Section II asimonov@hawaii.edu). 
provides literature review and develops my hypotheses. Section III presents the research design. The empirical results follow in Section IV. Section V concludes the paper.

\section{LITERATURE REVIEW AND HYPOTHESIS DEVELOPMENT}

The researchers in [14] define "a firm as investing efficiently if it undertakes projects with positive net present value (NPV) under the scenario of no market frictions such as adverse selection or agency costs." According to "q" theory, managers invest in projects until the marginal return is zero [6] and [7]. In this setting, there should not be any association between cash flow and investment [18]. If a firm needs cash to invest in NPV projects it raises the capital from capital markets. On the other hand, if the firm has excess cash, it distributes free cash flow to shareholders. However, market frictions and high transaction costs affect this association.

According to [17] corporate governance relates to the "ways in which suppliers of finance to corporations assure themselves of getting a return on their investment." Based on this definition, effective corporate governance should mitigate both under-investment and over-investment. However, prior literature is unclear on the role of governance in affecting investment efficiency.

In examining corporate governance association with investment efficiency, authors use different research designs to measure investment efficiency and different proxies for the corporate governance. Several studies find that investor protection reduces firm-level risk taking which in turn results in under-investment. Using data from 39 countries, researchers in [19] find that firm-level investment and firm growth are positively associated with investor protection. Managers in countries with low investor protection invest more into their firms. This results in a conservative firm-level investment and underfunding positive NPV projects. The stronger governance also encourages greater risk taking in the banking industry [20]. I can interpret these results as effective governance mechanisms mitigate under-investment.

Several studies find evidence that strong corporate governance mitigates over-investment but not underinvestment. At the firm-level, the authors in [15] find that firms with weaker governance metrics use excess cash to increase capital expenditures and acquisitions instead of paying dividends. The researchers in [21] construct an index that consists of antitakeover provisions. The authors show that capital expenditures are negatively associated with strong shareholder rights. In another study, the authors [22] demonstrate that in firms with poor governance managers pursue large investments more frequently compared to the firms with strong corporate governance. Based on the findings, the authors argue that poor governance associates with over-investment.

In order for the board of directors to mitigate underinvestment, board quality should be negatively associated with information asymmetry. The authors in [23], using three factors, board independence, board structure and board activity, find that changes in bid-ask spreads at the time of quarterly earnings announcements are significantly positively related to the board governance quality. Firms with high quality boards are associated with more frequent disclosures of quality information. These results are consistent with the hypothesis that firms with higher board governance quality have lower information asymmetry.

Effective boards also mitigate the moral hazard problem that potentially affects over-investment. Using the information generated by monitoring, boards regulate managers' capital investment decisions, which results in mitigating empire-building tendencies [24]. The researcher [16] finds that firms with certain weak board governance structures (firms with staggered boards and poison pills) experience higher levels of over-investment. Based on this discussion, I expect that effective board governance is negatively related to over-investment.

Summing up, literature provides mixed results on the relation between the board governance and firm-level investment. Although some authors argue that independent directors impose additional cost on the growing firms and firms investing into high-risk projects [25]-[27], I expect that strong board governance is positively related to investment efficiency for several reasons. Additional cost imposed by independent directors affects only some firms in specific industries. On the other hand, literature provides evidence that strong board governance reduces information asymmetry between investors and managers as well as it mitigates moral hazard problem. I anticipate reduced information asymmetry to mitigate under-investment and reduced hazard problem to mitigate over-investment. My hypotheses, in two parts, are stated bellow:

H1a: Firms with strong board governance are less likely to under-invest.

H1b: Firms with strong board governance are less likely to over-invest.

Professional and academic literature provides several definitions of the internal controls. SOX defines internal control over financial reporting (ICFR) as "a process ... affected by the company's board of directors ... to provide reasonable assurance regarding the reliability of financial reporting." This definition includes assurance regarding only financial reporting aspect. Most companies in implementing internal control system use the Committee of Sponsoring Organizations of the Treadway Commission (COSO) framework, which provides a broader definition of internal control. According to this definition, internal control is " a process, effected by an entity's board of directors, management and other personnel, designed to provide reasonable assurance regarding the achievement of objectives in the following three categories: 1 . Reliability of financial reporting, 2. Effectiveness and efficiency of operations, and 3. Compliance with applicable laws and regulations." The COSO framework definition incorporates not only the financial reporting aspect but also the effectiveness of operations, which include a high return on investment, improved market share, and new product introduction. According to COSO definition, internal controls should be positively associated with investment efficiency.

Disclosure of the ICFR weakness or strength provides information to the market on the effectiveness of the chief executive officers [28]. Chief executive officers expect more reliable information on their performance to be available to the market in case ICFR are effective. Thus, effective internal control is a strong incentive to improve the efficiency of the 
investment projects due to the chief executive officers' fair to lose their jobs. Effective ICFR reduces the moral hazard and potential over-investment.

I argue that there is a direct relation between internal control and investment efficiency, controlling for financial reporting quality. My second set of hypotheses is:

H2a: Effective internal control over financial reporting mitigates under-investment.

H2b: Effective internal control over financial reporting mitigates over-investment.

In studying investment efficiency and corporate governance, prior studies examine whether corporate governance mechanisms are effective in aligning managers' and shareholders' interest and whether the alignment is associated with investment efficiency. However, alignment of interest in itself is not sufficient for investment efficiency. Managers also need strong internal control over financial reporting to provide accurate information about investment projects to make efficient investment decisions. Prior literature tests the relation between investment efficiency and accuracy of information by examining quality of accounting information reported to the public [14] and [23]. At the same time, managers receive information about capital investment projects not only from external but also from internal reports [29]. The set of information from internal reports that could assist in investment decisions may include past and current patterns of sales, economic conditions, strategic changes in firm activities and planned changes in prices and product mix. Such information is essential for making investment decisions and effective ICFR positively correlates with high quality of both external and internal reports. Consequently, I anticipate that strong board governance alone will not result in the same degree of improvement in information efficiency as should exist if a firm has both strong government and effective ICFR.

Many academic studies examine the link between governance and internal controls [30] and [27]. An important question about the association between corporate governance and internal controls is whether board governance affects the firm's quality of internal control. Several studies support the view that a high quality board is associated with strong internal controls. The authors in [31] examine the association between board governance strength and disclosure of material weaknesses in internal control. They find that the likelihood of disclosure is related to audit committee and board governance quality. Other studies find that internal control quality enhances the effectiveness of board governance mechanisms [32].

Based on the above discussion above, I form the following hypotheses:

H3a: High quality board governance has stronger effect in mitigating under-investment when internal controls are effective.

$\boldsymbol{H} 3 \boldsymbol{b}$ : High quality board governance has stronger effect in mitigating over-investment when internal controls are effective.

\section{RESEARCH DESIGN}

I apply an unexplained investment approach to test whether board governance is associated with a reduction in firm over-investment or under-investment, after controlling for the firm's financial reporting quality. To perform the study, I identify firms that are more likely to over-invest and under-invest. I utilize the methodology used in [14] that compares the actual investment made by a firm in year $\mathrm{t}+1$ to that firm's predicted investment level. To test hypothesis H1a, H1b, H2a, H2b, H3a, and H3b that the low quality board governance and the disclosure of material weakness in ICFR are associated with investment inefficiency, I estimate a cross-sectional regression of investment levels between the firms with high quality board governance and firms with effective ICFR for the year prior to the initial disclosure of ICFR effectiveness.

Specifically, I estimate the following model using ordinary least squares.

$$
\begin{aligned}
& \quad \text { Invest }_{i, t+1}=\alpha_{0}+\alpha_{1} \text { Board }_{i, t}+\alpha_{2} \text { IC }_{i}+\alpha_{3} \text { OverI }_{i, t+1}+ \\
& \alpha_{4} \text { Board }_{i, t} * \text { OverI }_{i, t+1} \\
& \quad+\alpha_{5} I_{i, t} * \text { OverI }_{i, t+1}+\alpha_{6} \text { Board }_{i, t} * I C_{i}+\alpha_{7} \text { Board }_{i, t} * I C_{i} * \\
& \text { OverI }_{i, t+1} \\
& \quad+\sum \mathrm{\gamma}_{j} \text { Control }_{j, i, t}+\varepsilon_{i, t+1}
\end{aligned}
$$

I adjust standard errors using two-way cluster at the firm and year level [33]. I also include industry fixed-effects. Invest $_{i, t+1}$ is a measure of the total investment for a firm in year $t+1$ and is calculated as the sum of the capital expenditures, research and development expenditures, and acquisitions minus sales of property, plant, and equipment, scaled by lagged total assets and multiplied by 100 . The independent variable Board $\mathrm{d}_{\mathrm{i}, \mathrm{t}}$ is a measure developed by RiskMetrics Group. This variable is determined by adding up the weights associated with board strength rating factors. The weights are determined based on prior academic research and statistical tests. The indicators include board composition, whether CEO serves on the board, chairman and CEO separation, board attendance, board vacancies, related party transactions with CEO, board performance reviews, individual director performance reviews, meeting of outside directors, CEO succession plan, director education, majority voting, whether board has nominating, compensation, and governance committee. I classify firms based on their rank. Specifically, I assign 1 to the firm-year observations in the top $20 \%$ (i.e., the strongest board governance) and 0 to the firm year observations in the bottom $20 \%$ (i.e., the weakest board governance). I follow prior studies [34] and [14] and use year t determinants of the likelihood of over- and underinvestment to test the predictions. Prior studies indicate that cash rich and unlevered firms are more likely to over-invest. Based on this prediction, I separately rank cash balance and leverage multiplied by -1 into deciles. I average the cash and leverage ranks and then scale the average between 0 and 1 . I use the variable OverI to determine settings when firms are more likely to over- or under-invest.

When OverI=0, firms are financially constrained and are more likely to under-invest. Hence, I expect the coefficient $\alpha_{1}$ is to be positive. When OverI=1, the firms are more likely to over-invest. If firms with weak board governance overinvest compared to firms without strong governance, the sum of the coefficients $\alpha_{1}$ and $\alpha_{4}$ is expected to be negative. Thus, I expect $\alpha_{1}$ to be significantly positive for H1a (underinvestment) hypotheses and the sum of the coefficients $\alpha_{1}$ 
and $\alpha_{4}$ to be significantly negative for $\mathbf{H 1 b}$ (over-investment) prediction.

The indicator variable $I C$ equals 0 if auditors or management disclose ICFR material weakness for the first time and 1 otherwise. Similar to the methodology used to determine whether strong board governance is associated with investment inefficiency, if firms with an effective ICFR are prone to under-invest but invest more relative to the firms with ICFR material weaknesses, the coefficient $\alpha_{2}$ is expected to be positive (H2a hypotheses). If firms with effective ICFR are prone to over-invest but invest less compared to firms with ICFR material weaknesses, the sum of the coefficients on $\alpha_{2}$ and $\alpha_{5}$ is expected to be negative (H2b hypotheses).

To examine whether strong board governance has a stronger effect on investment inefficiency for firms with strong internal controls, I examine whether the sum of the coefficients $\alpha_{1}, \alpha_{2}$, and $\alpha_{6}$ is positive for firms prone to under-invest (H3a hypotheses). For firms that are more likely to over-invest, I test whether the sum of the coefficients $\alpha_{1}$, $\alpha_{2}, \alpha_{3}, \alpha_{4}, \alpha_{5}, \alpha_{6}$, and $\alpha_{7}$ are negative (H3b hypotheses). For firms with strong governance and weak ICFR in the under-investment setting, I expect coefficient $\alpha_{1}$ to be positive. For firms that are prone to over-invest, I test whether the sum of coefficients $\alpha_{1}, \alpha_{3}$, and $\alpha_{4}$ is negative.

\section{EMPIRICAL RESULTS}

Data for this study comes from several sources. The sample is restricted to U.S. firms for fiscal years 2004-2009. I exclude 2002-2003 fiscal years because data on ICFR material weaknesses is scarce. The main sample consists of 1,144 firm-year observations. I begin with all firm-year observations in Compustat between 2004 and 2009. Financial firms with SIC codes between 6000 and 6999 are eliminated from the sample due to differences in the nature of investments for these firms. I obtain information on disclosures about internal control effectiveness from Audit Analytics. I identified those disclosures from Audit Analytics 302 for quarterly and annual reports and from Audit Analytics 404 for the fiscal year reports. I eliminate firm-year observations without matching Audit Analytics data because this information is required to determine ICFR material weakness. This requirement eliminates a large number of observations due to missing CIK numbers from firms in Compustat and the reduced coverage of firms in Audit Analytics. I also remove firm-year observations without required data to determine board governance score. I truncate all continuous variables at the one present and 99 percent levels to mitigate the influence of outliers.

I use firm-level data for board governance variable from RiskMetrics Group. This database rates U.S. companies using different variables. The variables are weighted positively or negatively, with underlying weights determined based on academic research and statistical test. The variables with the highest weight include having board controlled by a supermajority of over $90 \%$ independent outside directors, having a fully independent audit committee, and having an audit committee that consists only of "financial experts." The creators of the index state that those factors determine what governance is about - to provide checks and balances on managers to align their interest with shareholders. Firms in an index group are then assigned an Index Score on a scale of 1 to 5 with 5 being the highest. For the test purposes, I scaled the score between 0 and 1 .

TABLE I: DESCRIPTIVE STATISTICS FOR THE SAMPLE

\begin{tabular}{|c|c|c|c|c|c|c|}
\hline Variable Label & $\mathrm{N}$ & Mean & Median & Std Dev & Minimum & Maximum \\
\hline Investment & 6732 & 0.20 & 0.11 & 0.29 & -0.05 & 2.84 \\
\hline Board & 6732 & 0.51 & 0.51 & 0.29 & 0.00 & 1.00 \\
\hline IC & 6732 & 0.09 & 0.00 & 0.28 & 0.00 & 1.00 \\
\hline AQ & 6732 & -0.05 & -0.04 & 0.03 & -0.01 & 0.00 \\
\hline MktBook & 6732 & 2.37 & 1.55 & 2.69 & 0.48 & 36.80 \\
\hline OverI & 6732 & 0.61 & 0.61 & 0.28 & 0.00 & 1.00 \\
\hline LogAsset & 6732 & 4.63 & 4.59 & 2.10 & -1.40 & 10.14 \\
\hline stvCFO & 6732 & 0.09 & 0.06 & 0.10 & 0.00 & 1.02 \\
\hline stvSale & 6732 & 0.19 & 0.14 & 0.19 & 0.00 & 1.37 \\
\hline stvInvestment & 6732 & 0.12 & 0.06 & 0.18 & 0.00 & 1.82 \\
\hline Tangibility & 6732 & 0.27 & 0.20 & 0.24 & 0.00 & 0.94 \\
\hline Kstructure & 6732 & 0.15 & 0.05 & 0.20 & 0.00 & 0.90 \\
\hline CFOsale & 6732 & -0.31 & 0.05 & 2.21 & -4.42 & 0.70 \\
\hline Dividend & 6732 & 0.27 & 0.00 & 0.44 & 0.00 & 1.00 \\
\hline OperCycle & 6732 & 4.72 & 4.78 & 0.77 & 1.78 & 7.59 \\
\hline Loss & 6732 & 0.42 & 0.00 & 0.49 & 0.00 & 1.00 \\
\hline SalesGrowth & 6732 & 0.27 & 0.13 & 0.71 & -0.95 & 10.26 \\
\hline Cash & 6732 & 0.23 & 0.14 & 0.23 & 0.00 & 0.93 \\
\hline Leverage & 6732 & -0.15 & -0.05 & 0.21 & -1.31 & 0.00 \\
\hline
\end{tabular}

Table I presents descriptive statistics for the dependent variables, test variables, and control variables. The mean level of Investment is about 20 percent of prior year's assets. The mean value of OverI is 0.61 (this variable is measured in deciles from 0 to 1.0). The variable AQ shows a distribution consistent with prior research with a mean value of -0.05 . The remaining control variables are consistent with prior research.

TABLE II: PEARSON CORRELATION

\begin{tabular}{lrllllllllllllll}
\hline \multicolumn{1}{c}{ Variable } & 1 & 2 & 3 & 4 & 5 & 6 & 7 & 8 & 9 & 10 & 11 & 12 & 13 & 14 & 15 \\
\hline 1 Invest & 1.00 & & & & & & & & & & & & & & \\
2 Overl & 0.12 & 1.00 & & & & & & & & & & & & & \\
3 Board & 0.02 & 0.00 & 1.00 & & & & & & & & & & & & \\
4 IC & 0.01 & 0.01 & 0.01 & 1.00 & & & & & & & & & & & \\
5 stvCFO & 0.25 & 0.23 & -0.02 & 0.00 & 1.00 & & & & & & & & & \\
6 stvSale & -0.02 & 0.04 & 0.02 & 0.01 & 0.37 & 1.00 & & & & & & & & & \\
7 stvlnvest & 0.40 & 0.00 & -0.01 & 0.01 & 0.18 & 0.05 & 1.00 & & & & & & & & \\
8 AQ & -0.03 & 0.01 & 0.00 & -0.04 & 0.03 & 0.01 & 0.03 & 1.00 & & & & & & & \\
9 Tangibility & -0.05 & -0.38 & 0.06 & 0.00 & -0.20 & -0.20 & 0.04 & 0.00 & 1.00 & & & & & & \\
10 CFOsale & 0.16 & -0.12 & 0.01 & 0.00 & -0.21 & 0.06 & -0.11 & -0.01 & 0.08 & 1.00 & & & & & \\
11 Dividend & -0.13 & -0.22 & 0.01 & -0.04 & -0.22 & -0.13 & -0.13 & 0.00 & 0.16 & 0.10 & 1.00 & & & & \\
12 OperCycle & -0.03 & 0.08 & 0.00 & 0.02 & 0.01 & -0.13 & -0.03 & -0.03 & -0.25 & -0.12 & -0.05 & 1.00 & & & \\
13 Loss & 0.13 & 0.14 & -0.05 & 0.06 & 0.27 & 0.09 & 0.16 & -0.15 & -0.04 & -0.23 & -0.31 & 0.04 & 1.00 & & \\
14 Cash & 0.20 & 0.75 & -0.05 & -0.01 & 0.26 & -0.01 & 0.08 & 0.02 & -0.39 & -0.22 & -0.22 & -0.01 & 0.20 & 1.00 & \\
15 Leverage & 0.03 & 0.74 & 0.01 & 0.02 & 0.11 & 0.04 & -0.05 & -0.01 & -0.24 & -0.04 & -0.10 & 0.14 & 0.01 & 0.34 & 1.00 \\
\hline
\end{tabular}

Table II reports Pearson correlation for all continuous variables. OverI is significantly associated with Investment with a correlation of 0.12 . The correlations between Board, IC and Investment are positive and significant (0.02 and 0.01, respectively), indicating that strong board governance and effective internal capture some investment dimensions. Correlations between the independent variables are consistent with prior literature and do not suggest potential multicolliniarity issues. 
Table III reports the results of my tests for my predictions and hypotheses using the model that controls for firm-level accounting quality. To evaluate the effects of strong governance and internal control strength on investment efficiency, I use a model that can differentiate the following cases: 1) firms with strong board but weak ICFR; 2) firms with weak board but strong ICFR; 3) firms with both strong board and strong ICFR. Consequently, this model answers the question whether board governance and internal control individually determines or jointly affect firms' investment efficiency.

TABLE III: CORPORATE GOVERNANCE, INTERNAL CONTROL AND INVESTMENT EFFICIENCY Invest $_{i, t+1}=\alpha_{0}+\alpha_{1}$ Board $_{i, t}+\alpha_{2} I C_{i}+\alpha_{3}$ Over $_{i, t+1}+\alpha_{4}$ Board $_{i, t} *$ Over $_{i, t+1}+\alpha_{5} I_{i, t} *$ Over $_{i, t+1}+$ $\alpha_{6}$ Board $_{i, t}{ }^{*} I_{i}+\alpha_{7}$ Board $_{i, t}{ }^{*} I_{i}{ }^{*}$ OverI $_{i, t+1}+\sum \mathrm{\gamma}_{j}$ Control $_{j, i, t}+\varepsilon_{i, t+1}$

\begin{tabular}{|c|c|c|c|c|}
\hline Variable & Hypothesis & $\begin{array}{l}\text { Predicted } \\
\text { Sign }\end{array}$ & $\begin{array}{l}\text { Parameter } \\
\text { Estimate }\end{array}$ & t Value \\
\hline Intercept & & $?$ & $0.26 * * *$ & 4.50 \\
\hline Board (1) & H1a Under-investment & + & $0.12 *$ & 1.95 \\
\hline Board*OverI (2) & & - & -0.21 & -0.96 \\
\hline IC (3) & H2a Under-investment & + & $0.10 * *$ & 2.08 \\
\hline IC*OverI (4) & & - & $-0.36 * *$ & -2.27 \\
\hline $\operatorname{OverI}(7)$ & & $?$ & $0.16 * *$ & 2.16 \\
\hline Board*IC (5) & & $?$ & $0.32 * * *$ & 2.66 \\
\hline Board*IC*OverI (6) & & - & $-0.58 * * *$ & -3.01 \\
\hline$(\mathbf{1})+(\mathbf{2})$ & H1b Over-Investment & - & $-0.09 *$ & 3.70 F-value \\
\hline$(3)+(4)$ & H2b Over-Invest & - & $-0.26 * *$ & 4.31 F-Value \\
\hline BaordStrong ICStrong (1)+(3)+(5) & H3a Under-Invest & + & $0.54 * * *$ & 8.09 F-value \\
\hline BoardStrong ICStrong (1)+(2)+(3)+(4)+(5)+(6)+(7) & H3b Over-Invest & - & $-0.45 * *$ & 4.93 F-value \\
\hline BaordStong ICWeak (1) & Under-Invest & + & $0.12 *$ & 1.95 \\
\hline BoardStrong ICWeak (1)+(2)+(7) & Over-Invest & - & 0.07 & 0.32 F-value \\
\hline $\mathrm{AQ}$ & & + & $0.09 * * *$ & 2.78 \\
\hline $\mathrm{AQ}{ }^{*}$ OverI & & - & $-0.25 * * *$ & -3.44 \\
\hline LogAsset & & - & $0.00 * * *$ & 3.44 \\
\hline MktBook & & + & $0.03 * * *$ & 5.19 \\
\hline stvCFO & & $?$ & $0.09 * * *$ & 4.72 \\
\hline stvSale & & $?$ & -0.01 & -1.51 \\
\hline stvInvestment & & $?$ & $0.15 * * *$ & 21.18 \\
\hline Tangibility & & $?$ & -0.03 & -0.21 \\
\hline CFOsale & & $?$ & $0.00 *$ & -1.67 \\
\hline Slack & & $?$ & $0.00 * *$ & 2.21 \\
\hline Dividend & & - & $-0.04 * * *$ & -5.08 \\
\hline OperCycle & & $?$ & -0.03 & -1.22 \\
\hline $\begin{array}{l}\text { Loss } \\
R^{2}\end{array}$ & & $?$ & $\begin{array}{l}0.03 * \\
28.07 \%\end{array}$ & 1.78 \\
\hline
\end{tabular}

The positive and significant coefficient on $I C$ indicates that actual investment is higher for firms as their likelihood of under-investing increases when ICFR is effective. In other words, consistent with H2a prediction, firms with strong internal control increase investment level if they are more likely to under-invest. The significant and negative coefficient for $I C+I C * O v e r I$ indicate that firms with strong internal controls decrease investment level if they are prone to under-investing, supporting $\mathbf{H 2 b}$ hypotheses. The coefficients for Board and Board+Board*IC are consistent with H1a and H1B hypothesis. Firms are less likely underinvest and over-invest when they have strong board governance. Thus, both effective internal controls and strong board governance, considered separately, are important in mitigating over-investment and under-investment.

Next, the model indicates that both strong board governance and effective ICFR significantly increase investment for firms prone to over-investment, given the positive and significant coefficient for the test (H3b hypotheses). The results are even stronger for the firms with strong board governance and effective internal controls in a setting when firms are more likely to under-invest $(\mathbf{H 3 a}$ hypotheses).
Additionally, I examine whether strong board governance is effective in mitigating under- and over-investment when internal controls are weak. The results are significant (with $10 \%$ significance) for the firms with strong board governance but weak internal controls, indicating that board governance is effective in mitigating information asymmetry and reducing the cost of capital when internal controls are weak. On the other hand, in the same settings the results are insignificant for the firms that are prone to over-investing. This indicates that strong board governance is ineffective in mitigating managers' empire-building tendencies when internal controls are ineffective.

\section{CONCLUSION}

This study investigates whether board governance affects the investment efficiency and whether this effect is stronger for the firms with effective internal controls over financial reporting, after controlling for a firm's overall level of financial reporting quality. Contrary to the claim made by the author in [28] that the increased role of independent directors on the boards decreases risk-taking by U.S. businesses and results in reduction in investment levels, suggesting 
ineffective investment, I find weak evidence that strong board governance enhances firm's investment efficiency. On the other hand, this study finds that board governance combined with strong internal controls over financial reporting results in greater investment efficiency. This is consistent with the assumption that for investment efficiency, managers' and shareholders' interests should be aligned and managers should have accurate information to make the investment decisions. If any of those conditions fail, we cannot not expect to observe investment efficiency. Strong board governance aligns interests' of managers and shareholders. On the other hand, effective internal control insures that managers receive accurate information not only from external but also from internal reports.

This study contributes to existing research by combining the literature on board governance, internal control, earnings quality, and investment efficiency. Bridging the gap allows me to analyze whether board governance provides important benefits above and beyond other incentives that affect a firm's financial reporting quality. Finally, the study provides evidence about the board governance' influence on the real operating decisions of by firm management. Overall, the results should be of interest to investors who want to allocate capital more efficiently and managers and shareholders who determine the board structure.

\section{CONFLICT OF INTEREST}

The author declares no conflict of interest.

\section{AUTHOR CONTRIBUTIONS}

Andrey Simonov is a single author of this paper. He had approved the final version of the paper.

\section{REFERENCES}

[1] United States Census Bureau, 2017.

[2] T. Klammer, B. Koch et al., "Capital budgeting practices-A survey of corporate use," Journal of Management Accounting Research, vol. 3, pp. 113-130, 1991.

[3] B. M. Burton, A. A. Lonie et al., "The stock market reaction to investment announcements: The case of individual capital expenditure projects," Journal of Business Finance \& Accounting, vol. 26, no. 5/6, pp. 681-708, 1999.

[4] J. J. McConnell and C. J. Muscarella, "Corporate capital expenditure decisions and the market value of the firm," Journal of Financial Economics, vol. 14, no. 3, pp. 399-422, 1985.

[5] M. Harris and A. Raviv, "A theory of board control and size," Rev. Financ. Stud., vol. 21, no. 4, pp. 1797-1832, 2008.

[6] F. Hayashi, "Tobin's marginal q and average q: A neoclassical interpretation," Econometrica, vol. 50, no. 1, pp. 213-224, 1982.

[7] H. Yoshikawa, "On the 'q' theory of investment," American Economic Association, vol. 70, no. 4, pp. 739-743, 1980.

[8] G. Habbard, "Capital-market imperfections and investment," Journal of Economic Literature, vol. 36, pp. 193-225, 1998.

[9] S. C. Myers, "The capital structure puzzle," Journal of Finance, vol. 39, no. 3, pp. 575-592, 1984.

[10] M. C. Jensen, W. H. Meckling et al., Theory of the Firm: Managerial Behavior, Agency Costs, and Ownership Structure, pp. 214-275, 1986.

[11] O. J. Blanchard, F. Lopez-de-Silanes et al., "What do firms do with cash windfalls?" Journal of Financial Economics, vol. 36, no. 3, pp. 337-360, 1994

[12] R. Morck, A. Shleifer et al., "Do managerial objectives drive bad acquisitions?" Journal of Finance, vol. 45, no. 1, pp. 31-48, 1990.

[13] P. G. Berger and R. Hann, "The impact of SFAS no. 131 on information and monitoring," Journal of Accounting Research, vol. 41, no. 2, pp. 163-223, 2003.
[14] G. C.Biddle, G. Hilary et al., "How does financial reporting quality relate to investment efficiency?" Journal of Accounting \& Economics, vol. 48, no. 2/3, pp. 112-131, 2009.

[15] J. Harford, S. Mansi et al., "Corporate governance and firm cash holdings in the US," Journal of Financial Economics, vol. 87, 2008.

[16] S. Richardson, "Over-investment of free cash flow," Review of Accounting Studies, vol. 11, no. 2-3, pp. 159-189, 2006.

[17] J. Tirole, The Theory of Corporate Finance, Princeton University Press, 2005.

[18] F. Modigliani and M. H. Miller, "The cost of capital, corporation finance and the theory of investment," American Economic Review, vol. 48, no. 3, pp. 261-297, 1958.

[19] J. Kose, L. Litov et al., "Corporate governance and risk-taking," Journal of Finance, vol. 63, no. 4, pp. 1679-1728, 2008.

[20] L. Laeven and R. Levine, "Bank governance, regulation and risk taking," Journal of Financial Economics, vol. 93, no. 2, pp. 259-275, 2009.

[21] P. Gompers, J. Ishii et al., "Corporate governance and equity prices," Quarterly Journal of Economics, vol. 118, no. 1, p. 107, 2003.

[22] M. Billett, J. Garfinkel et al., "The influence of governance on investment: Evidance from a hazard model," Journal of Financial Economics, vol. 102, pp. 643-670, 2011.

[23] K. Kanagaretnam, G. J. Lobo et al., "Does good corporate governance reduce information asymmetry around quarterly earnings announcements?" Journal of Accounting and Public Policy, vol. 26, no. 4, pp. 497-522, 2007.

[24] P. Kumar and K. Sivaramakrishnan, "Who monitors the monitor? The effect of board independence on executive compensation and firm value," Review of Financial Studies, vol. 21, pp. 1371-1401, 2008.

[25] J. L. Coles, N. D. Daniel et al., "Boards: Does one size fit all," Journal of Financial Economics, vol. 87, no. 2, pp. 329-356, 2008.

[26] K. M. Lehn, S. Patro et al., "Determinants of the size and composition of US corporate boards: 1935-2000," Financial Management (Blackwell Publishing Limited), vol. 38, no. 4, pp. 747-780, 2009.

[27] L. L. Bargeron, K. M. Lehn et al., "Sarbanes-oxley and corporate risktaking," Journal of Accounting and Economics, vol. 49, no. 1-2, pp. 34-52, 2010.

[28] R. W. Masulis, C. Wang et al., "Agency problems at dual-class companies," Journal of Finance, vol. 64, no. 4, pp. 1697-1727, 2009.

[29] G. Cassar and B. Gibson, "Budgets, internal reports, and manager forecast accuracy," Contemporary Accounting Research, vol. 25, no. 3, pp. 707-737, 2008.

[30] L. Bebchuk, A. Cohen et al., "What matters in corporate governance?" Rev. Financ. Stud, vol. 22, no. 2, pp. 783-827, 2009.

[31] U. Hoitash, R. Hoitash et al., "Corporate governance and internal control over financial reporting: A comparison of regulatory regimes," Accounting Review, vol. 84, no. 3, pp. 839-867, 2009.

[32] B. W. Goh, "Audit committees, boards of directors, and remediation of material weaknesses in internal control," Contemporary Accounting Research, vol. 26, no. 2, pp. 549-579, 2009.

[33] M. Petersen, "Estimating standard errors in finance panel data sets: Comparing approaches," Review of Financial Studies, vol. 22, pp. 435480, 2009.

[34] T Opler, L. Pinkowitz et al., "The determinants and implications of corporate cash holdings," Journal of Financial Economics, vol. 52, no. 1, pp. 3-46, 1999.

Copyright $\odot 2020$ by the authors. This is an open access article distributed under the Creative Commons Attribution License which permits unrestricted use, distribution, and reproduction in any medium, provided the original work is properly cited (CC BY 4.0).

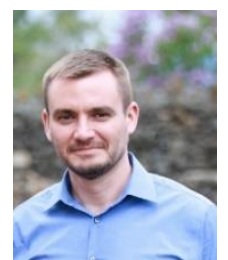

Andrey Simonov was born in Gvardeysk, Russia. He received his bachelor of arts in political science from Berea College, Berea, Kentucky in 2005; the master of accountancy degree from University of Louisville, Louisville, Kentucky in 2007; the Ph.D. in accounting from Louisiana State University, Baton Rouge, Louisiana in 2014.

Currently, he is an assistant professor in the University of Hawaii at Hilo. Prior to joining University of Hawaii, he was an assistant professor in Washington State University, worked as an auditor for KPMG, and as a chief financial officer for a printing company.

Dr. Simonov received many awards including Lloyd Morrison Award for excellent teaching. He is a member of the UH-Hilo Faculty Congress, Scholarship, External Affairs, Student Affairs and several other committees. 